\title{
JEAN-CLAUDE MICHÉA. EL IMPERIO DEL MAL MENOR: ENSAYO SOBRE LA CIVILIZACIÓN LIBERAL. 180 PÁGS. SANTIAGO, 2020: INSTITUTO DE ESTUDIOS DE LA SOCIEDAD.
}

\author{
Lukas Echegaray Hartmann \\ Universidad de los Andes, Santiago de Chile
}

La presente edición del intelectual francés llega a nuestras manos ahora en español, la cual incluye un prólogo de Daniel Mansuy y Manfred Svensson. El conocimiento de ambos en el campo de la filosofía política nos permite apreciar un comentario nutrido y, a la vez, agudo, que clarifica las ideas centrales del texto. Una de estas es la "supuesta idea transgresora" de la izquierda -apuntan Mansuy y Svensson- que cree estar luchando contra la globalización capitalista, pero no hace más que reforzar las condiciones de su existencia. Así, este tipo de ironías de la izquierda y el progresismo es apuntado por Michéa a lo largo de toda su obra.

Aunque el filósofo y profesor se formó políticamente en la izquierda, sus ideales se convirtieron posteriormente, más bien, en críticos de ella. Su crítica se funda en un análisis profundo sobre la civilización contemporánea y su comentario consistente contra el culto a la corriente progresista y el individualismo. No obstante, señala Michéa, el liberalismo no siempre se manifestó de la misma manera, por lo que propone investigar los orígenes de la política liberal, y describir su manifestación política en la actualidad. Veremos así que la profundidad del libro no radica únicamente en el análisis político, sino en el examen de la civilización contemporánea, la cual tiene un arraigado carácter liberal.

A pesar de la brevedad del libro, Michéa logra establecer una sólida unidad del liberalismo, y se atreve a inmiscuir en su origen. Aquel hito yace en las guerras de religión del s. XVII, el cual generó una actitud pesimista en la teoría política moderna. En aquel entonces, la concepción de la naturaleza humana ya no consistía en ideales morales como principio de una ciudad armoniosa. Por el contrario, la visión hobbesiana del hombre, según la cual este se encuentra en guerra consigo mismo en su estado de naturaleza, domina en gran parte del pensamiento político de la tradición moderna. Esta última consideraba al hombre más bien como es, y no como debe ser; anhelando simplemente la paz entre los individuos, y ya no su perfección. El deseo de la gloria y las virtudes heroicas fueron reducidas a una comprensión individualista, como máscara del amor propio y el interés privado, lo que Paul Bernichou denomina "la demolición de los héroes". De esta manera, señala Michéa, se funda el imperio del mal menor. 
No obstante, Michéa subraya también un optimismo en las ciencias, cuyo método equilibrista y su capacidad de dominio es absorbido completamente por el hombre moderno. Este es uno de los motivos que lo lleva a confiar plenamente en la razón: remueve la figura tradicional de la autoridad y establece un mecanicismo como ideología neutral. Michéa destaca este optimismo en la Razón como la principal característica de la Modernidad, y que perdura (casi de manera religiosa) en la actualidad. Por tanto, la crítica del autor trasciende el liberalismo como fenómeno político, y lo aborda como un constituyente de la civilización occidental moderna. Por ello, el subtítulo del libro es Ensayo sobre la civilización liberal.

Aquel aspecto genealógico referido anteriormente resulta fundamental en su argumentación, ya que permite concebir la libertad de conciencia y el libre mercado como parte de uno y el mismo fenómeno. En otras palabras, la libertad de la actividad económica no se ha desarrollado separadamente de la esfera social, sino que ha prosperado gracias a las condiciones sociales y culturales del individualismo desde sus inicios. Por este motivo, el autor aborda los aspectos liberales de las categorías políticas, tanto de la izquierda como de la derecha, como componentes de la misma sustancia liberal. O, para ser más preciso: el multiculturalismo de la izquierda y el libre mercado o neoliberalismo de la derecha se desenvuelven, según el autor, bajo la misma lógica individualista.

Así, desde el comienzo del libro, Michéa aborda el desarrollo del liberalismo mediante dos aspectos: el derecho y el mercado. Por un lado, el primero consiste en la constitución de reglas mínimas y comunes garantizadas por el Estado, las que neutralizan los intereses de los individuos. De esta manera, el Estado se convierte en una estructura de gobierno impersonal e irreflexiva que no impone ninguna concepción particular de la vida buena. Bajo la neutralidad liberal subyace el axioma kantiano de la ley, cuyo mecanismo es suficiente para asegurar la paz y coexistencia entre los individuos, incluso "en un pueblo de demonios". Por el otro lado, el mercado tiene el mismo propósito neutralizante al permitir a los individuos desplegar libremente la actividad económica según su propio interés, generando una armonía natural y una coexistencia pacífica. Por ende, ambos aspectos -el derecho y el mercado- conforman la unidad del liberalismo, que no tiene otro fin que el de la coexistencia pacífica en la sociedad mediante "el equilibrado sistema de peso y contrapeso" de los intereses.

No obstante, Michéa describe de forma aguda un cambio de perspectiva en el liberalismo. En la sociedad actual de Occidente, la política liberal no consiste en tan solo un recurso desesperado ante los conflictos políticos. Ahora, el imperio del mal menor "quiere ser adorado como el mejor de los mundos". En otras palabras, la libertad individual se convierte en un ideal de perfección de la naturaleza humana. Por tanto, el individualismo es más que una solución que rehúye de los conflictos: la 
prosperidad pública adquiere una apariencia moral mediante el regocijo del interés privado. La "sociedad abierta" o "multicultural" se corona con los laureles de un orden moral décadent (diría Nietzsche), en el que el progreso moral se reduce a actitudes como el respeto y la benevolencia, calificadas por Michéa como "una buena conciencia a bajo costo".

He aquí el máximo esplendor del progresismo, en el que la doctrina egoísta se impone a los individuos. De este modo, el progreso no solo otorga libertades a los individuos, sino que también los compele a ser egoístas (lo que supuestamente debiese ser espontáneo). Por este motivo, Michéa describe el progresismo como un liberalismo avasallador, en el que el individuo moralista debe sacrificar su interés por disuadir a otros para vivir pacíficamente su privacidad. Así, bajo el amparo del derecho, la lógica individualista propia del mercado es protegida de "cualquier contaminación ideológica”.

Ante el vasallaje del progresismo y su optimismo en las ciencias positivas, el intelectual francés advierte un mayor pesimismo en las capacidades del hombre para amar y ser decente. Esto se trasluce en el constante recurso a las ideas de George Orwell y la continua referencia a la "decencia común" a lo largo de todo el libro. Estas nociones representan una nostalgia por lo humano, lo que ha sido olvidado y aniquilado por un imperio adulador del hombre egoísta. El exagerado optimismo del progresismo ante las ciencias y las tecnologías confunde al hombre contemporáneo, y lo llevan a recurrir, con cierto dejo salvífico, a la historia como la resolución de los problemas y de las contradicciones de la humanidad.

En conclusión, el autor francés demuestra ser consciente de los efectos negativos del proyecto progresista. Incluso, lo exhibe como un proyecto con un enfoque distinto al del liberalismo tradicional, el cual no sería avalado por exponentes como Adam Smith o Benjamin Constant (según el autor). La exacerbada crítica de Michéa nos interpela a qué hacer para no perder lo humano; cómo vivir en la sociedad contemporánea sin perder lo nuestro. Ante ello, el político se erige como la única respuesta, pero en medio de un ambiente en que la política tiene un carácter meramente instrumental. Atrás quedó el arte de gobernar de los antiguos sabios. Quizás, a lo lejos, es posible distinguir la figura del conservador. No obstante, requiere de una estricta autocrítica para desmarcarse de la perniciosa corriente individualista que inunda cada vertiente de la política. 